\title{
A Distribution Communication Network Scheme Involving DERs in Power Grid
}

\author{
Nanhua Yu, Xiaoping Zhang \\ Electric Power Science Research Institute of \\ Guangdong Power Grid Corporation \\ Guangzhou, China \\ E-mail: ynhzy2@163.com
}

\author{
Xinyu Wang, Runze Wu,Wenxia Liu \\ School of Electrical and Electronic Engineering \\ North China Electric Power University \\ Beijing, China \\ E-mail: skysmile_w@hotail.com
}

\begin{abstract}
DER access to the distribution network will change the characteristics of power flow, the network short-circuit current levels and introduce a large number of harmonic interference in the traditional distribution network, which requires effective communication scheme as a monitor. In this paper, we analyze the requirements of the distribution of business and DER grid monitoring business, combined with the characteristics of a various types of communication, give a communication scheme of distribution network containing DERs. The program can be used as a reference for future distribution communication network construction with certain practical value.
\end{abstract}

Keywords- DER ; Distribution businesses ; Distribution communication scheme

\section{INTRODUCTION}

DER generally defined as a joint system combined with small generators or power generation and energy storage devices to meet the needs of end users. The generating capacity of DER are generally between tens kilowatts to tens of megawatts ${ }^{[1]}$. However, the DER on grid are in the pilot phase due to the shocks of DER on the grid has not been effectively addressed. DER access to the distribution network will change the characteristics of power flow, the network short-circuit current levels and introduce a large number of harmonic interference in the traditional distribution network ${ }^{[2-3]}$. The effect above will affect the accuracy and stability of the grid action, include the relay protection, voltage regulation, as well as the static stability of the distribution network. The problem is rooted in the unsmooth exchange of information among DERs and the power distribution system, which leads to difficulty of DER in timely action with the system equipment operation ${ }^{[4]}$.

In this paper, we analyze the requirements of the distribution of business and DER grid monitoring business, combined with the characteristics of a various types of communication, give a communication scheme of distribution network containing DERs. The program can be used as a reference for future distribution communication network construction with certain practical value.

\section{DISTRIBUTION COMMUNICATION BUSINESS DEMAND}

\section{A. Business segments of distribution with DER}

Information type of power system communication can generally be divided into teleindication, telemetry, telecommand and teleadjustment. Distribution communication business can be divided into teleindication, telemetry, telecommand in accordance with the monitoring information.

The corresponding distribution node is divided into "one remote", "two remote" and "three remote". One remote have the function of telemetry, two remote have teleindication, telemetry, while three have all the three ${ }^{[5]}$. To achieve DER smoothly incorporated into the distribution network, we should on the one hand have the power under monitor; on the other hand, DER needs timely and effective control. When the power generation does not match the merge network standard, timely action should be taken to avoid impact of the entire grid security. DER access to the grid needs effective teleindication, telemetry and telecommand. That is to say, DER acts as a three remote node when incorporated into the distribution network.

\section{B. business needs analysis of distribution grid with DER}

Construction of communication network needs to consider bandwidth and reliability requirements of the distribution node. Bandwidth is communication business transmitted per second. Reliability is the uninterrupted and accuracy of the data transmission.

1) Bandwidth requirements analysis

For a single distribution network node, we define the information type as I:

$\mathrm{I}=\{\mathrm{I} 1$ - teleindication,I2- telemetry,I3- telecommand $\}$; Specific class of I defined as:

$$
C_{j}=\left\{C_{i, j}, i=1,2,3 ; j \in[1, M]\right\}
$$

Polling time defined as:

$$
T_{i}=\left\{T_{i, j}, i=1,2,3 ; j \in[1, M]\right\}
$$

Number of targets to be monitored in $\mathrm{C}_{\mathrm{j}}$ defined as:

$$
\left\{N_{j}, j \in[1, M]\right\}
$$

Bytes number of each $\mathrm{C}_{\mathrm{j}}$ defined as:

$$
\left\{D_{j}, j \in[1, M]\right\}
$$

The total bandwidth of the node is:

$$
B=\sum_{i=1}^{3} \sum_{j=1}^{M} \frac{C_{i, j} \times N_{j} \times D_{j}}{T_{i, j}}
$$

That is to say, total bandwidth equals the weighted sums of each type of information, which is the business transmitted per second. 
Assuming a substation covers $\mathrm{K}$ distribution node, the total bandwidth requirement of the substation is $\mathrm{K}^{*} \mathrm{~B}$ 。

\section{2) Reliability Analysis}

For all type information, the real-time and reliability requirements showed in the following table:

TABLE I. RELIABILITY REQUIREMENTS OF INFORMATION

\begin{tabular}{|c|c|c|}
\hline data & real-time requirements & reliability index \\
\hline telemetry & $\begin{array}{l}\text { Change telemetry } 5 \sim 15 \mathrm{~s} \\
\text { transfer to host }\end{array}$ & $\begin{array}{l}\text { Telemetry qualified } \\
\text { percent of pass is } 98 \%\end{array}$ \\
\hline $\begin{array}{l}\text { Teleindi- } \\
\text { cation }\end{array}$ & $\begin{array}{l}\text { Information transmitted to the } \\
\text { master less than } 5 \mathrm{~s} \text {, special } \\
\text { channels (GPRS) can be } \\
\text { relaxed to the } 10 \mathrm{~s}\end{array}$ & $\begin{array}{ll}\text { The teleindication } \\
\text { action correct rate } \geq \\
99.9 \%\end{array}$ \\
\hline $\begin{array}{l}\text { Telecom- } \\
\text { mand }\end{array}$ & $\begin{array}{l}\text { General finished less than } 5 \mathrm{~s} \text {, } \\
\text { special channels relaxing to } \\
15 \mathrm{~s}\end{array}$ & $\begin{array}{l}\text { telecommand accuracy } \\
\geqslant 99.9 \% \text {; } \\
\text { The remote integrated } \\
\text { error } \leqslant 0.5 \%\end{array}$ \\
\hline
\end{tabular}

The real-time requirements is the transmission delay of the signal between transceiver and endpoints, reliability is the credibility of the received information after the distortion or error in the transfer process.

\section{C. communication needs of DER access to the grid}

The main type of DER including the internal combustion engine, battery, micro turbine, biomass power, fuel cells, geothermal, solar power, wind power, tidal power. In accordance with the stability of the output power, DER are classified in Table 2 .

\section{TABLE II. DER CLASSIFICATION}

\begin{tabular}{ll}
\hline \multicolumn{1}{c}{ power quality } & \multicolumn{1}{c}{ DER } \\
\hline output stable & $\begin{array}{l}\text { Internal combustion engine, battery, micro gas } \\
\text { turbine, bioenergy power generation, fuel cell } \\
\text { (main fuel: light oil and natural gas), small } \\
\text { hydropower, geothermal }\end{array}$ \\
$\begin{array}{l}\text { Output relatively } \\
\text { stable }\end{array}$ & $\begin{array}{l}\text { Solar power (photovoltaic power generation, } \\
\text { photochemical power generation, light } \\
\text { induction power and light chemical power } \\
\text { generation) } \\
\text { Wind energy, tidal, etc }\end{array}$ \\
\hline
\end{tabular}

According to the State Grid Corporation of wind farm grid technology (for trial implementation) and Technical rule for connecting PV power station to electric power systems ${ }^{[6]}$, certain management should be taken to keep the access smoothly. The management include: power management, voltage management, power quality management and fault management. As shown below.

TABLE III. DER MANAGEMENT INFORMATION

\begin{tabular}{|c|c|}
\hline management name & content \\
\hline power & active power control \\
\hline & $\begin{array}{lll}\text { reactive } & \text { power } & \begin{array}{l}\text { reactive capacity } \\
\text { reactive power supply }\end{array}\end{array}$ \\
\hline voltage & voltage range, voltage deviation \\
\hline power quality & $\begin{array}{l}\text { harmonic and waveform distortion, dc component, } \\
\text { frequency, voltage deviation, voltage unbalance } \\
\text { degree, voltage fluctuation and flicker }\end{array}$ \\
\hline fault & $\begin{array}{l}\text { mainly is the control information, including } \\
\text { increase the whole impedance of component, } \\
\text { power grid restructuring or stepout }\end{array}$ \\
\hline
\end{tabular}

According to IEC 61850, we select the internal combustion engine, PV power and wind power as a typical case. The communication business of the accessing to the grid summarized as table III.

Easy to see, DER access to the grid needs teleindication, telemetry and telecommand. It is a "three remote".

\section{TABLE IV. TYPICAL DER ACCESSING BUSINESS}

\begin{tabular}{ll}
\hline \multicolumn{1}{c}{ DER } & \multicolumn{1}{c}{ communication service of grid-connection } \\
\hline $\begin{array}{l}\text { micro gas } \\
\text { turbine }\end{array}$ & $\begin{array}{l}\text { Power frequency and the frequency after inverter and } \\
\text { phase Angle, engine speed, engine torque, check point } \\
\text { before the engine timing, blow by flow } \\
\text { photovoltaic } \\
\text { power } \\
\text { generation } \\
\text { small scale } \\
\text { wind power } \\
\text { generation }\end{array}$ \\
$\begin{array}{l}\text { horizontal plane Angle (with seasonal adjustment), and } \\
\text { north to east position angle }\end{array}$ \\
$\begin{array}{l}\text { Meteorological parameters (including wind speed, wind } \\
\text { direction, environment temperature); unit state } \\
\text { parameter detection (rotor speed, generator speed, } \\
\text { generator coil temperature, generator and bearing } \\
\text { temperature, gear box oil temperature, gear box and } \\
\text { bearing temperature, hydraulic system oil temperature, } \\
\text { oil pressure, oil level, the engine vibration, cable new } \\
\text { turn, the engine temperature, etc.) }\end{array}$ \\
\hline
\end{tabular}

\section{ADAPTIVE ANALYSIS OF COMMUNICATION}

There are a variety of distribution communication modes. The distribution communication topology can be divided into the backbone layer, access layer and aggregation layer according to the corresponding voltage level ${ }^{[7]}$. Technologies in backbone layer including SDH / MSTP, access layer including industrial Ethernet technology, EPON, PLC and rental of wireless public network, while, aggregation layer including fieldbus, RS-485, dial-up telephone, as well as electric power line. Communication mode and its applicable business are shown in table $\mathrm{V}$.

\begin{tabular}{|c|c|c|}
\hline TABLE V. & $\begin{array}{l}\text { CHARACTERISTICS OF THE PRIMARY } \\
\text { AND ITS APPLIES BUSINESS }\end{array}$ & MMUNICATION \\
\hline $\begin{array}{c}\text { communication } \\
\text { technology }\end{array}$ & technical features & $\begin{array}{c}\text { professional } \\
\text { work }\end{array}$ \\
\hline $\begin{array}{l}\text { MSTP base on } \\
\text { SDH }\end{array}$ & $\begin{array}{l}\text { Business bandwidth flexible } \\
\text { configuration, large transmission } \\
\text { capacity, automatic load balance, } \\
\text { fast convergence and rapid recovery }\end{array}$ & $\begin{array}{l}\text { telemetry } \\
\text { teleindication } \\
\text { telecommand }\end{array}$ \\
\hline $\begin{array}{l}\text { industrial } \\
\text { ethernet }\end{array}$ & $\begin{array}{l}\text { Communication speed, real time } \\
\text { higher; Good adaptability, low cost, } \\
\text { stable and reliable; Suitable for } \\
\text { sudden data transmission }\end{array}$ & $\begin{array}{l}\text { telemetry } \\
\text { teleindication }\end{array}$ \\
\hline EPON & $\begin{array}{l}\text { Large capacity, dynamic bandwidth } \\
\text { allocation, fast transmission speed, } \\
\text { good stability, Extensibility is poor } \\
\text { relatively }\end{array}$ & $\begin{array}{l}\text { telemetry } \\
\text { teleindication } \\
\text { telecommand }\end{array}$ \\
\hline PLC & $\begin{array}{l}\text { low constuction cost; free topology, } \\
\text { the great flexibility; Transmission } \\
\text { characteristics with strong time- } \\
\text { varying characteristics }\end{array}$ & $\begin{array}{l}\text { telemetry } \\
\text { teleindication }\end{array}$ \\
\hline $\begin{array}{l}\text { Wireless public } \\
\text { network(GPRS) }\end{array}$ & $\begin{array}{l}\text { Permanent online, mature } \\
\text { technology, extensive network } \\
\text { coverage; big data transmission } \\
\text { delay, high operation cost, low } \\
\text { security }\end{array}$ & $\begin{array}{l}\text { telemetry } \\
\text { teleindication }\end{array}$ \\
\hline field bus & High cost, small suitable scale & telemetry \\
\hline
\end{tabular}




\section{DISTRIBUTION COMMUNICATION SCHEME WITH DER}

\section{A. The selection of specific communication method}

DER generally access in the $10 \mathrm{kv}$ or lower voltage level grid. The total capacity and monitoring requirements of DER are shown in table VI.

TABLE VI. DER MONITORING PRINCIPLES

\begin{tabular}{cc}
\hline capacity of DER & require \\
\hline$<200 \mathrm{~kW}$ & $\begin{array}{c}\text { No monitor } \\
200 \mathrm{~kW} \sim 1 \mathrm{MW}\end{array}$ \\
$>1 \mathrm{MW}$ & $\begin{array}{c}\text { If use of relay protection to prevent the } \\
\text { distributed power inject energy to system, } \\
\text { do not need monitoring } \\
\text { monitor }\end{array}$ \\
\hline
\end{tabular}

The wiring style and accompanying communication lines of DER accessing to the grid are shown in figure1.

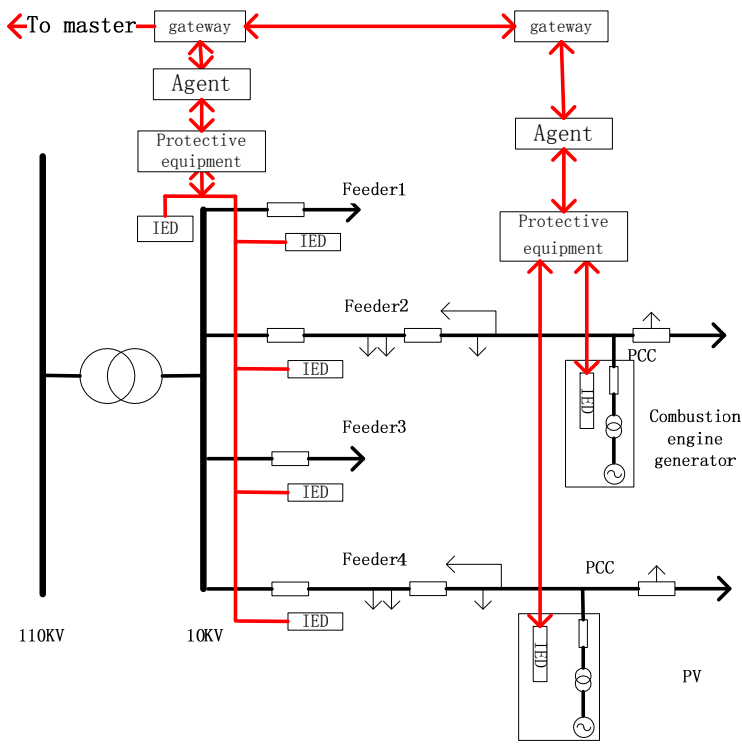

Figure 1. Wiring diagram of DER accessing into the grid

Incorporated into distribution network as a load point, DER is belonging to three remote point. So the communication mode should be optical fiber which provides high level capacity and relatively.

The design of the scheme should take the current state of communication lines into consideration and meet the requirement with minimum cost. The one remote node in the aggregation layer can take any mode. A two remote nodes requirement needs industrial Ethernet or leasing public networks. Three remote nodes use fiber-optic as main means.

\section{B. Networking structure analysis}

Distribution communication network can be roughly divided into three layers: the backbone layer, access layer and aggregation layer. Backbone layer mainly response to the communication among masters and the receiving information from substation and controlling substation run. Access layer collects and classifies the information from aggregation layer and passes them to the master. Aggregation layer is mainly responsible for collecting information from the terminal and upload to the upper layer. DER should be classified in the aggregation layer as a power point. The network structure is shown below.

The medium of backbone layer communication should be optical fiber, both SDH ring network and fiber optic Ethernet communication can be chosen. Industrial Ethernet, $\mathrm{SDH}$, and broadband wireless communication are main options of access layer. Three remote point in the convergence layer should use fiber optic communication, other nodes refer to the local network construction and communication needs to choose communication means.

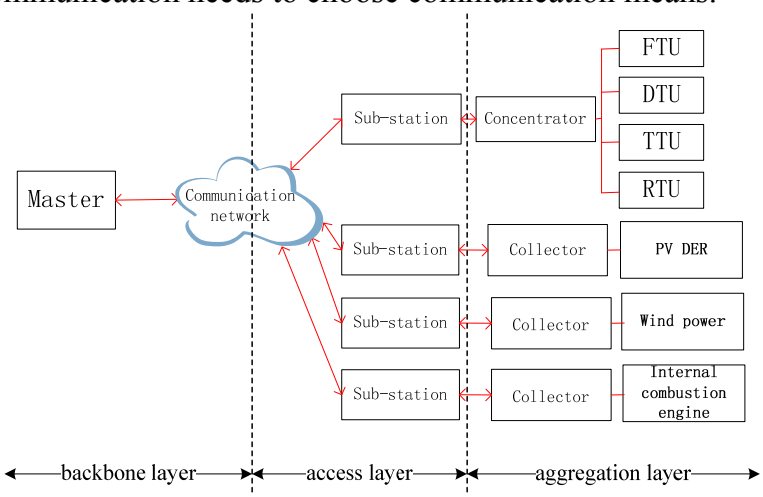

Figure 2. Network structure of DER access to the grid

\section{Description of the implementation of the schame}

A region is centralized power supply by the grid with a long-term electricity peak-to-valley, which has obvious impact on the equipment. The region has a $10 \mathrm{kv}$ distribution transformer covers rich solar energy. In order to balance valley, the local grid company planning to have a small internal combustion engine access into the grid as a supplement of the centralized power. The PV capacity can be up to $5 \mathrm{MW}$, and the internal combustion engine about $2 \mathrm{MW}$. The consumption in the region is $15 \mathrm{MW}$ so that the grid and DERs should work as power supplement at the same time.

Both the two types of DERs need to monitor and management. Survey of the local communication shows that the backbone layer communication style is $\mathrm{SDH}$ ring structure. And there is a total of 150 distribution node in the region, including 86 one remote points that is mainly used to collect electricity information, 53 two remote points with 22 for teleindication and 31 for both telemetry and teleindication, 11 three remote points include the planed two DERs.

One remote node is used to measure, the main business type are switching status, fault indicator information, switching charged signal, the SF6 switch pressure signals the accident trip signal protection action signal and the abnormal signal, the terminal state signal, the communication state signal. The bandwidth of each signal class single less than 1 byte, but taking the overhead bytes and independence into account, we leave one byte for each telemetry signal, and all the information need to be uploaded to the sub-station within $5 \mathrm{~s}$

Business types of two remote node the various types of 
data on the channels, clock calibration data, displacement telesignalling data and changing telemetry data. 22 nodes with function of teleindication needs 2 bytes, the others need 3 bytes. Teleindication information uploads within 3 s, and the telemetry information within $5 \mathrm{~s}$.

The three remote node conclude all kind of information, and teleindication signal needs 1 byte, teleindication single needs 2 bytes, and telecommand needs 5 bytes. All requirements upload within 3s.Assuming a switchgear has 2 incoming line and 2 outgoing line, Ethernet frame overhead 18 bytes, the TCP / IP header 20 bytes, the bandwidth requirements of the various types of nodes can calculate according to 2.2. then match with the communication type. The scheme of network is shown below:

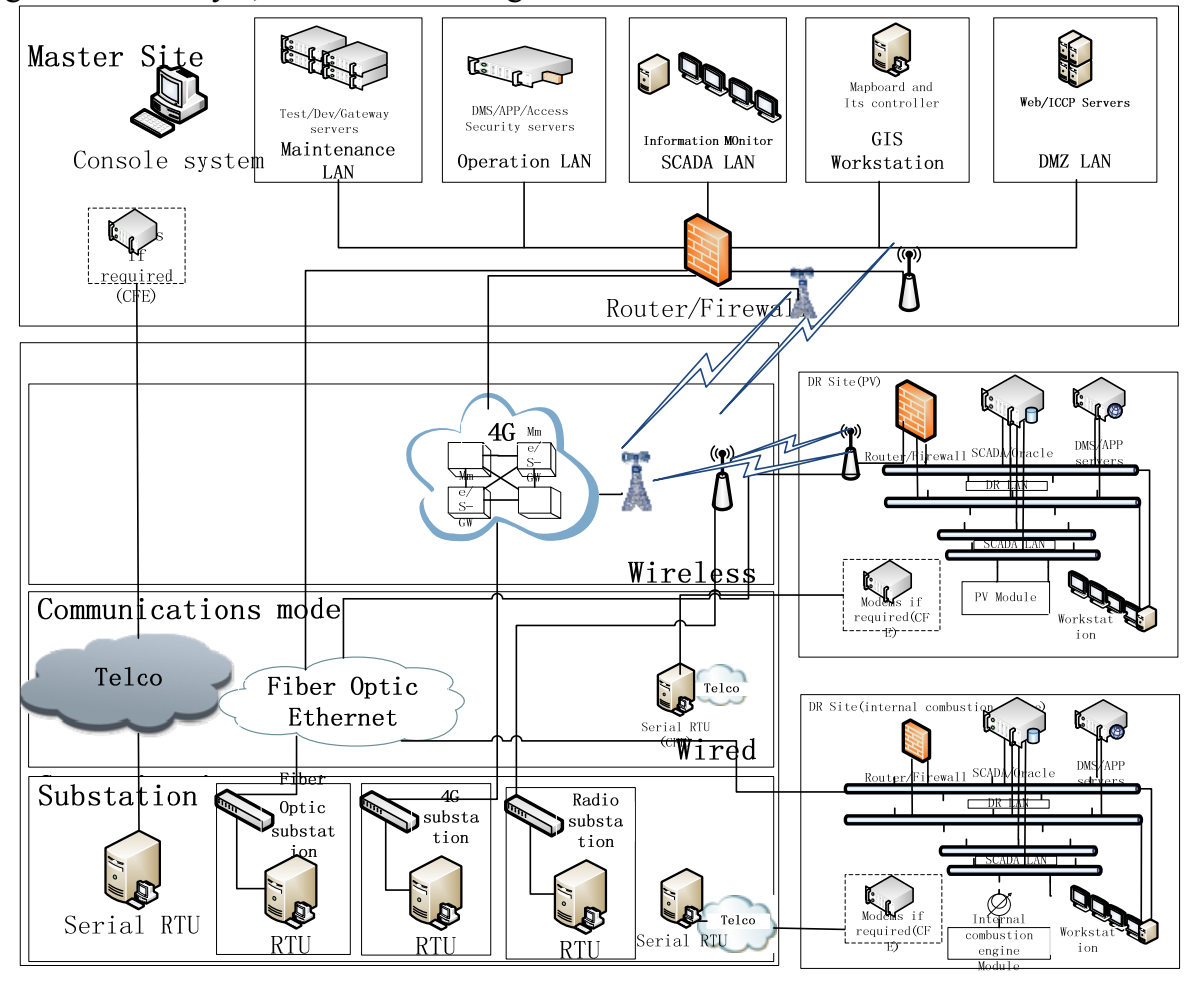

Figure 3. Network scheme of distributed grid with DER

\section{CONCLUSION}

This paper analyzes the distribution business requirements including DERs and the adaptability of different communication type. Finally, we give a description of distribution communication solutions with one case. The program has considered the electricity business demand for bandwidth and reliability, which can be used as a reference in the future distribution communication network construction. At the same time, the program can be improved in the perspective of economy.

\section{ACKNOWLEDGMENT}

Thank National High Technology Research and Development Program (863,2012AA050212) for the funding supporting.

\section{REFERENCES}

[1] C. Li, "Distributed Generation and the Technology of Its Parallel Operation on Power System," Journal of Shanghai University of Electric Power, vol.24(3), pp. 77-281, 2008
[2] J. C. Yu, F. J. Chi, K. Xu, "Analysis of the Impact of Distributed Generation on Power Grid," Proceedings of the Chinese Society of Universities, col. 24(1), pp.138-141,2012

[3] F. Hong, J. F. Chen, X. Z Duan, "Current Research and Prospect of development of the micro-network," Higher schools in China electric power system and its automation professional papers of the twentyfourth annual meeting.2008, pp.2661-2666

[4] IEC 61850-7-420-2009. "Communication networks and systems for power utility automation - Part 7-420: Basic communication structure - Distributed energy resources logical nodes". International Electrotechnical Commission,2009-3

[5] Q. Zhong, "A design of distribution grid automation communication system". Science \& Technology Information,vol. 13, pp. 138$138,2011$.

[6] GB/Z 19964-2005. "Technical rule for connecting PV power station to electric power systems". General Administration of Quality Supervision, Inspection and Quarantine \&\& China National Standardization Management Committee.2005-12-12

[7] X. R. Liu, "Study on Communication System Plan and Evaluation Method in the Distribution Automation". North China Electric Power University,2009 